\title{
Estimates of soil losses by the erosion potential method in tropical latosols
}

\author{
Estimativas de perdas de solo pelo método de erosão potencial \\ em latossolos tropicais
}

\section{Guilherme Henrique Expedito Lense ${ }^{1}\left(\mathbb{D}\right.$, Taya Cristo Parreiras ${ }^{1}\left(\mathbb{D}\right.$, Rodrigo Santos Moreira ${ }^{1} \mathbb{D}$, Junior Cesar Avanzi² ${ }^{(D)}$, Ronaldo Luiz Mincato ${ }^{1 *}$ iD}

\author{
'Universidade Federal de Alfenas/UNIFAL-MG, Alfenas, MG, Brasil \\ 2Universidade Federal de Lavras/UFLA, Lavras, MG, Brasil \\ *Corresponding author: ronaldo.mincato@unifal-mg.edu.br \\ Received in May 17, 2019 and approved in August 6, 2019
}

\begin{abstract}
Water erosion is one of the main problems faced in coffee cultivation, as it promotes environmental degradation and crop yield decrease. Erosion estimates support the planning of conservation management practices and allowing determining the rates of soil losses. Thus, the objective of this paper was to estimate the soil loss by water erosion using the Erosion Potential Method in a sub-basin predominantly covered by coffee cultivation and then to compare the results with the Soil Loss Tolerance limits. The study area is the Coroado Stream Sub-basin, located at Alfenas Municipality, south of Minas Gerais, Brazil. The sub-basin presented an Erosion Coefficient of 0.272 , indicating a predominance of low-intensity erosion. The total soil loss estimate was 1,772.01 $\mathrm{Mg}$ year-1 $^{-1}$ with an estimated average of $1.74 \mathrm{Mg}^{-1}$

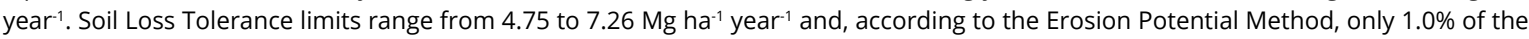
sub-basin presented losses above the limits. The areas with the highest slopes and bare soil concentrated the highest losses rates and should be prioritized in the adoption of mitigation measures. The Erosion Potential Method estimated soil losses in tropical edaphoclimatic conditions in a fast, efficiently and at low cost, supporting the adoption of conservation management practices.
\end{abstract}

Index Terms: Soil conservation; water erosion; modeling.

\section{RESUMO}

A erosão hídrica é um dos principais problemas enfrentados na cafeicultura, pois promove a degradação ambiental e a diminuição da produção agrícola. As estimativas da erosão auxiliam no planejamento de práticas e sistemas de manejo conservacionistas e permitem aferir as taxas de perdas do solo. Assim, o objetivo do trabalho foi estimar a perda de solo por erosão hídrica pelo Método de Erosão Potencial em uma sub-bacia hidrográfica com cultivo predominante de café e, então, comparar com os limites de Tolerância de Perda do Solo. A área de estudo correspondente a uma Sub-bacia Hidrográfica do Córrego Coroado, Município de Alfenas, sul de Minas Gerais, Brasil. O Método de Erosão Potencial apresentou o Coeficiente de Intensidade da Erosão de 0,272, indicando predomínio da erosão de fraca intensidade. A perda potencial total de solo foi de 1.772,01 $\mathrm{Mg}_{\text {ano-1 }} \mathrm{com}$ média estimada em 1,74 $\mathrm{Mg} \mathrm{ha}^{-1} \mathrm{ano}^{-1}$. Os limites de Tolerância de Perda do Solo variaram de 4,75 a 7,26 Mg ha-1 ano-1 e segundo o Método de Erosão Potencial apenas 1,0\% da sub-bacia apresentou perdas acima do limite de tolerância. As maiores taxas de perdas de solo se encontram nas áreas com maiores declividades e presença de solo exposto e devem ser priorizadas na adoção de medidas mitigadoras. O Método de Erosão Potencial estimou as perdas de solo nas condições edafoclimáticas tropicais de forma rápida, eficiente e com baixo custo, subsidiando a adoção de práticas agronômicas conservacionistas.

Termos para indexação: Conservação do solo; erosão hídrica; modelagem.

\section{INTRODUCTION}

Brazil is the world's largest coffee producer and exporter, with 2 million hectares planted. Coffee cultivation is a relevant source of income and an important sector in job creation for hundreds of cities. In the environmental point of view, Brazilian coffee cultivation should seek to conserve soil and biodiversity, providing a socioeconomic and environmental sustainable production (Brazil, 2018).

One of the problems faced by coffee growers, especially in tropical areas with the steepest slope, is water erosion. This phenomenon reduces the availability of fertile soils and water quality, promoting environmental degradation of cultivated lands and compromising the sustainability of 
the system (Scharrón; Sánchez, 2017). Besides sediment transport, the phenomenon causes the removal of nutrients, agrochemicals, contaminants and organic matter, reducing the productive capacity of the land and generating additional costs to the producers (Avanzi et al., 2013). The soil losses due to water erosion in the areas with temporary and permanent crops in Brazil are of the order of 822.7 million tons per year, generating an average financial loss of $\mathrm{R} \$ 6.6$ billion per year (Hernani et al., 2002).

Researches on the mechanisms and intensity of water erosion in the coffee crop are limited (Prochnow et al., 2005; Carvalho et al., 2007; Scharrón; Sánchez, 2017; Mendes Júnior et al., 2018; Tavares et al., 2019). Thus, it is necessary to adopt instruments that provide erosion data in tropical areas under coffee cultivation to proposing possible mitigating practices (Sánchez et al., 2015).

Erosion modeling methods estimate soil loss rates and, when associated with Geographic Information Systems (GIS), allow the visualization of the spatial distribution of the areas most susceptible to erosion, providing information that contributes to the improvement of agricultural productivity and prevention and mitigation of environmental impacts (Couto Júnior et al., 2019).

The Erosion Potential Method (EPM) (Gavrilovic, 1988) is a soil loss estimation model used in the former Yugoslavia, Balkan regions, Eastern Europe, Middle Orient, Italy, North Africa and, more recently, in Brazil (Stefanidis; Stathis, 2018; Tavares et al., 2019). EPM has acceptable accuracy and provides similar results to established methods such as the Revised Universal Soil Loss Equation (RUSLE) (Renard et al., 1997) and the Universal Soil Loss Equation (USLE) (Wischmeier; Smith, 1978), with the advantage of having a simple structure and requiring little input data (Efthimiou et al., 2016; Tavares et al., 2019). Another advantage of the EPM is the retention coefficient $\left(R_{u}\right)$ (Gavrilovic, 1988), that provides an estimate of the fraction of the eroded sediment that reaches the water body system and the fraction that was deposited in relief depressions, which is not possible by USLE and RUSLE.

The erosion prediction allows identifying areas with soil losses above the Soil Loss Tolerance (T) limit. T is a parameter that reflects the maximum erosion rate that will still allow the crops to achieve sustainable production (Wischmeier; Smith, 1978). The T value is of great importance for taking measures to control water erosion on agricultural lands, helping to prioritize the most affected areas. The ideal soil erosion rate consists of the equivalent of soil formation. However, due to the variability of the pedogenetic factors, determined the soil formation rates with precision is not possible ( $\mathrm{Li}$ et al., 2009). Thus, in the short-term, T can be used as a soil sustainability index, but in the long term, the productive capacity of agricultural land requires the reduction of erosion rates close to zero (Mendes Júnior et al., 2018).

Thus, this paper aims to estimate soil loss rate by water erosion using the Erosion Potential Method (EPM) in a sub-basin predominantly cultivated with coffee, and compare the results with the Soil Loss Tolerance (T) limit.

\section{MATERIAL AND METHODS}

\section{Study area}

The study area is the Coroado Stream Hydrographic Sub-basin, affluent of the Furnas Hydroelectric Power Plant reservoir at coordinates UTM 403784 to $406399 \mathrm{~m} \mathrm{~W}$ and 7620076 to $7616515 \mathrm{~m} \mathrm{~S}$, zone 23K, Datum SIRGAS 2000 (Figure 1). The area belongs to the Rio Grande Hydrographic Basin and is placed at the Capoeirinha coffee farm (Ipanema Agrícola SA), in the Alfenas Municipality, southern of Minas Gerais, Brazil. The climate of the region according to the Köppen classification is Tropical Mesothermic (CwB) (Sparovek; Van Lier; Dourado Neto, 2007).

The land use map (Figure 1) was made using ArcGIS 10.3 software (ESRI, 2015), based on field surveys and images of the Landsat- 8 Operational Land Imager (OLI) satellite, bands 2, 3, and 4, in orbit 219, point 75, from the Image Generation Division (DIDGI) (INPE, 2019). The sub-basin presents coffee cultivation, native and regenerating forests as predominant land uses with 406.89 ha and 345.52 ha, respectively. Others land use classes include corn (65.50 ha), sugarcane (60.11 ha), eucalyptus (38.43 ha), pasture (13.09 ha), drainage (32.11 ha), facilities (14.44 ha) and access roads (39.90 ha).

The digital soil map was elaborated using topography as the basic attribute of soil formation (Mcbratney; Santos; Minasny, 2003), combined with field morphological descriptions and laboratory physical and chemical analyzes of soil samples. Digital Elevation Model (DEM) was obtained based on the level curves from the Topographic Chart of Alfenas (IBGE, 1970) and the declivity Map was elaborated from the DEM by the ArcGIS 10.3 Slope tool (ESRI, 2015) (Figure 2A).

Disturbed and undisturbed soil samples were collected in 27 points at the $0-20$ and $20-60 \mathrm{~cm}$ soil layers (Figure 2A) according to the relief and the soil use classes using a probe and a cylindrical sampler $\left(92.53 \mathrm{~cm}^{3}\right)$, respectively. The depth and morphological description of each soil were made in micro trenches $(40 \times 40 \times 60 \mathrm{~cm})$ (Santos et al., 2005). The particle size distribution was analyzed by pipette method with $0.1 \mathrm{~mol} \mathrm{~L}^{-1} \mathrm{NaOH}$ as a dispersant (Gee; Bauder, 1986), the soil density from samples with undisturbed structure (Blake; Hartge, 1986) and the soil organic matter content according to Embrapa (2011). 


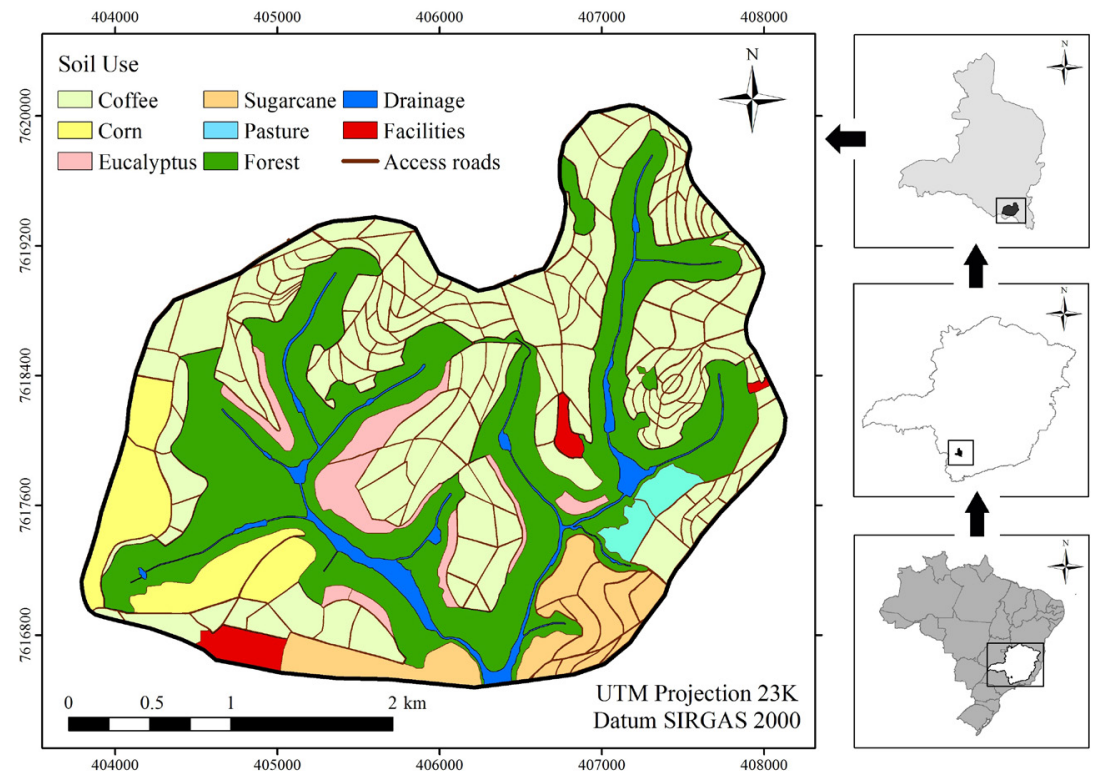

Figure 1: Map of the location and land use of the Coroado Stream Sub-basin, Alfenas, south of Minas Gerais, Brazil.

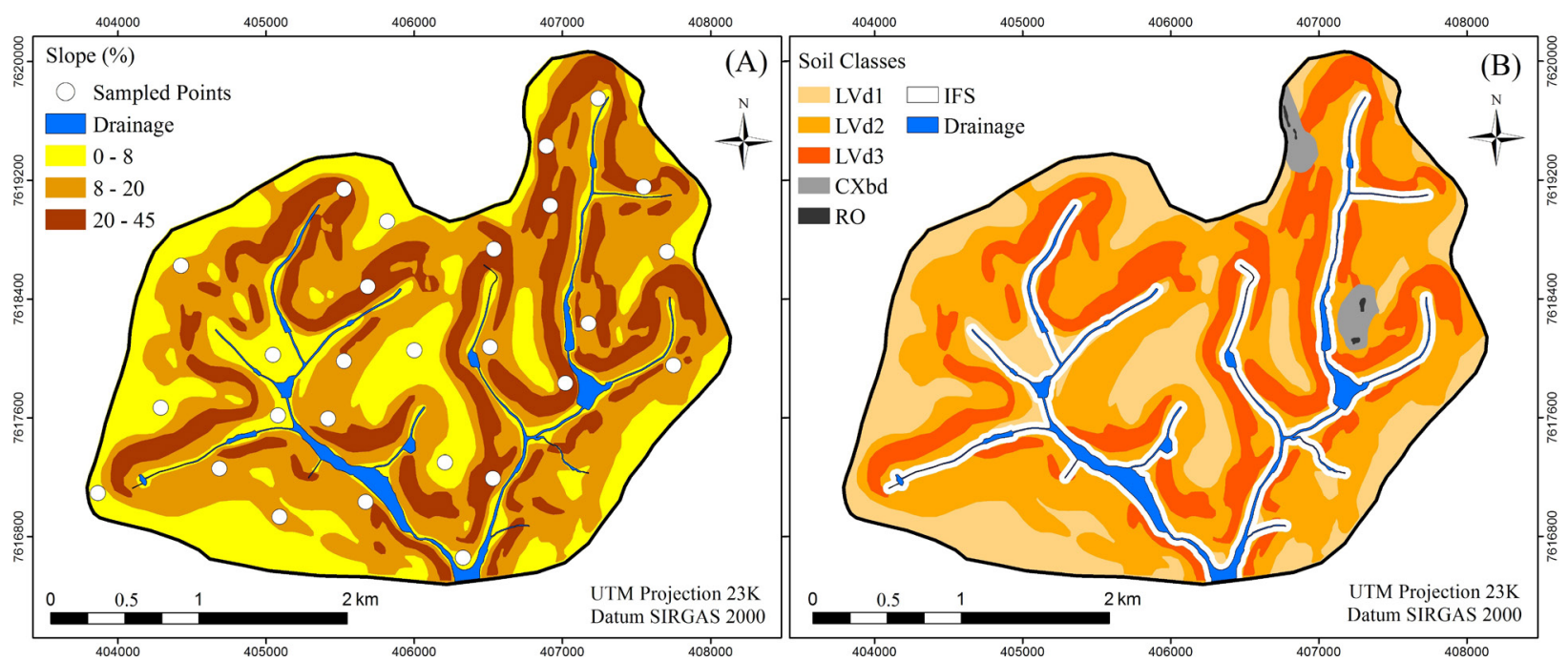

Figure 2: Declivity map with soil sampling points (A) and Digital Soil Map (B) of the Coroado Stream Hydrographic Sub-basin, Alfenas, south of Minas Gerais, Brazil. Notes: dystrophic Red Latosol in flat to slightly rolling relief (LVd1), rolling relief (LVd2), and strongly rolling relief (LVd3), dystrophic Tb Haplic Cambisol (CXbd), indiscriminate floodplain soils (IFS) and Rocky Outcrop (RO).

The soils were classified according to the Embrapa (2013) as a dystrophic Red Latosol (Oxisol - USDA, 1999 ) in flat to slightly rolling relief - LVd1 (slope 0-8\%), rolling relief - LVd2 (slope 8-20\%), strongly rolling relief - LVd3 (slope of 20-45\%) dystrophic Tb Haplic Cambisol (CXbd) (Inceptisol - USDA, 1999) and indiscriminate floodplain soils (IFS) (Figure 2B), corresponding to $24.07,46.58,20.32,1.74$ and $4.13 \%$ of the area, respectively.

\section{Erosion Potential Method (EPM)}

The annual soil loss was estimated by the Erosion Potential Method (EPM) (Gavrilovic, 1988) using the mathematical model shown in Table 1. 
Table 1: Equations and descriptions of the parameters used to estimate soil losses in the Erosion Potential Method.

\begin{tabular}{|c|c|c|}
\hline Equation & & Parameters \\
\hline $\mathrm{W}_{\mathrm{yr}}=\mathrm{T}_{\mathrm{c}} \cdot \mathrm{H}_{\mathrm{yr}} \cdot \pi \cdot \sqrt[2]{\mathrm{Z}^{3}} \cdot \mathrm{F} \cdot \mathrm{Ds}$ & (1) & $\begin{array}{l}\mathrm{W}_{\mathrm{yr}}=\text { Annual erosion }\left(\mathrm{Mg} \mathrm{yr}^{-1}\right) \\
\mathrm{T}_{c}=\text { Coefficient of temperature (dimen.) } \\
H_{\text {w }}=\text { Mean annual rainfall }\left(\mathrm{mm} \mathrm{yr}^{-1}\right)\end{array}$ \\
\hline $\mathrm{G}_{\mathrm{yr}}=\mathrm{W}_{\mathrm{yr}} \cdot \mathrm{R}_{\mathrm{u}}$ & (2) & $\begin{array}{l}\mathrm{Z}=\text { Coefficient of erosion (dimen.) } \\
\mathrm{F}=\text { Study area }\left(\mathrm{km}^{2}\right) \\
\mathrm{Ds}^{*}=\text { Soil density }\left(\mathrm{kg} \mathrm{dm}^{-3}\right)\end{array}$ \\
\hline $\mathrm{Tc}=\sqrt[2]{\frac{\mathrm{t}_{0}}{10}}+0.1$ & (3) & $\begin{array}{l}\mathrm{G}_{\mathrm{yr}}=\text { Sediment production }\left(\mathrm{Mg} \mathrm{yr}^{-1}\right) \\
\left.\mathrm{R}_{\mathrm{u}}=\text { Coefficient of retention (dimen. }\right) \\
\mathrm{t}_{0}=\text { Mean air temperature }\left({ }^{\circ} \mathrm{C} \mathrm{yr}^{-1}\right)\end{array}$ \\
\hline$Z=Y \cdot X_{a} \cdot\left(\varphi+\sqrt[2]{I_{s r}}\right)$ & (4) & $\begin{array}{l}Y=\text { Soil resistance to erosion (dimen.) } \\
X_{a}=\text { Coefficient of soil use and management (dimen.) } \\
\varphi=\text { Coefficient of visible erosion features (dimen.) }\end{array}$ \\
\hline $\mathrm{R}_{\mathrm{u}}=\frac{(\mathrm{O} \cdot \mathrm{D})^{0,5}}{0.25 \cdot(\mathrm{L}+10)}$ & (5) & $\begin{array}{l}\mathrm{I}_{\mathrm{sr}}=\text { Mean slope }(\%) \\
\mathrm{O}=\text { Basin length }(\mathrm{km}) \\
D=\text { Difference in basin elevation }(\mathrm{m}) \\
L=\text { Length of basin }(\mathrm{km})\end{array}$ \\
\hline
\end{tabular}

Notes: dimen. = dimensionless. * Parameter incorporated into the original formula for conversion of $\mathrm{m}^{3}$ year ${ }^{-1}$ to $\mathrm{Mg}_{\mathrm{gear}}{ }^{1}$. Source: Gavrilovic (1988).

The sub-basin area is $10.16 \mathrm{~km}^{2}(\mathrm{~F})$ with a perimeter of $13.54 \mathrm{~km}(\mathrm{O})$ and a minimum, average and maximum altitude of 793, 860 and $940 \mathrm{~m}$, respectively. The sub-basin length has an extension of $3.32 \mathrm{~km}(\mathrm{~L})$, measured by the watercourse, and the mean difference in elevation (D) is $67 \mathrm{~m}$, calculated by the ratio of the mean and the minimum altitude. The physical characteristics were obtained in GIS, by geoprocessing based on the Topographic Chart of Alfenas (IBGE, 1970).

The coefficient of erosion $(Z)$ represents the intensity of the erosive process. $Z$ values close to 0 represent lower severity of water erosion. Soil resistance to erosion $(\mathrm{Y})$ changes according to type of soil and its source material. Their values are tabulated from 0.20 to 2.0. The smaller the $\mathrm{Y}$, the greater the soil resistance to erosion (Gavrilovic, 1988). In this work, the $\mathrm{Y}$ value was 0.8 and 0.9 for the Latosols and the CXbd, respectively. The adoption of a greater index for the CXbd indicates its higher susceptibility to erosion compared to the Latosols (Bertol; Almeida, 2000).

According to soil use and management, it is possible to determine the soil protection coefficient $\left(\mathrm{X}_{\mathrm{a}}\right)$, which expresses the protection of an area against soil aggregates breakdown. Values range from 0.05 for areas with dense vegetation to 1.0 , for areas without vegetation. The coefficient of visible erosion features $(\varphi)$ is obtained from visual characterization of the erosive processes degree. The $\varphi$ values range from 0.1 in areas with no evident erosive features to 1 in areas with severe erosion (Gavrilovic, 1988). The values of $X_{a}$ and $\varphi$ were obtained from field surveys throughout the sub-basin, classifying each class of soil use according to the values tabulated by Gavrilovic (1988) (Table 2). The INMET (2019) database was used to determine the climatic factors $\left(\mathrm{H}_{\mathrm{yr}}, \mathrm{t}_{0}\right)$ while the mean slope $\left(\mathrm{I}_{\mathrm{sr}}\right)$ was determined by declivity map.

The EPM was developed to estimate soil loss in river basins (Gavrilovic, 1988). Thus, in this study, the entire sub-basin was considered, and not only the coffee growing area, the main objective of the research.

The model calculation was performed by the IntErO software (Spalevic, 2011) and the spatial distribution of soil losses was done in ArcGIS 10.3 (ESRI, 2015) by the Raster Calculator tool, generating the map of erosion estimation.

\section{Soil loss tolerance $(\mathrm{T})$}

The soil loss tolerance $(\mathrm{T})$ was calculated according to the Equation 6 proposed by Bertol and Almeida (2000):

$\mathrm{T}=100 \cdot \mathrm{h} \cdot \mathrm{r}_{\mathrm{a}} \cdot \mathrm{m} \cdot \mathrm{p} \cdot \mathrm{Ds} \cdot 1000^{-1}$

Where: $\mathrm{T}$ is the soil loss tolerance $\left(\mathrm{Mg} \mathrm{ha}^{-1} \mathrm{ano}^{-1}\right)$; $\mathrm{h}$ is the effective soil depth $(\mathrm{cm})$, limited to $100 \mathrm{~cm} ; \mathrm{r}_{\mathrm{a}}$ is the ratio that expresses, mutually, the effect of the textural relationship between the horizons $\mathrm{B}$ and $\mathrm{A}$ and the clay content of the horizon $\mathrm{A} ; \mathrm{m}$ is the factor that expresses 
the organic matter content in the $0-20 \mathrm{~cm}$ soil depth; $p$ is the soil permeability factor; Ds is the soil density $(\mathrm{kg}$ $\left.\mathrm{dm}^{-3}\right)$ e 1.000 is the constant that represents the time period required to wear a soil layer of $1000 \mathrm{~mm}$ depth.

The $r_{a}$ parameter used the clay content and the textural relationship between the superficial $(0-20 \mathrm{~cm})$ and subsurface layers $(20-60 \mathrm{~cm})$. The textural relations were lower than 1.5 , and the value of $r_{a}$ was weighted according to Bertol and Almeida (2000) in 1.0, 0.9 and 0.8 , according to the soil clay content.

For the $\mathrm{m}$ factor, values of $1.00,0.85$ and 0.70 were attributed to areas with organic matter contents above than 5.0, between 5.0 and 2.5 and below than 2.5 dag $\mathrm{kg}^{-1}$, respectively. The soil permeability was classified according to Galindo and Margolis (1989) considering the information of soil texture and structure development degree. Soil permeability factor (p) values were 1.00, 0.85 and 0.70 for the fast, moderate and slow class, respectively (Bertol; Almeida, 2000). The potential soil loss estimated by EPM were compared with the $\mathrm{T}$ limits.

\section{RESULTS AND DISCUSSION}

The sub-basin annual average of rainfall is 1500 $\mathrm{mm}\left(\mathrm{H}_{\mathrm{yr}}\right)$ and the mean temperature is $22^{\circ} \mathrm{C}\left(\mathrm{t}_{0}\right)$ (INMET, 2019). The temperature coefficient $\left(T_{c}\right)$ was calculated based on $\mathrm{t}_{0}$, obtaining the value of 1.52. $\mathrm{H}_{\mathrm{yr}}$ and $\mathrm{T}_{\mathrm{c}}$ are the active climatic factors that directly influence the disintegration of soil particles (Wischmeier; Smith, 1978).
The study area showed good soil resistance to water erosion with a Y value of 0.803 (Gavrilovic, 1988). The LVd1, LVd2, and LVd3 showed a granular with moderate-degree and medium-sized structure while the Cambisol had an angular blocks structure with weakdegree and medium-sized. The dystrophic Red Latosols and Cambisol exhibited a consistency classified as slightly plastic and non-plastic, respectively. The average soil density was $1.21 \mathrm{~kg} \mathrm{dm}^{-3}$ with a mean depth of 2.60 , 2.58, 2.45 and $0.71 \mathrm{~m}$ for LVd1, LVd2, LVd3, and CXbd, respectively.

The clay content ranged from 29.10 to $61.20 \%$. Cambisol was classified as a sandy clay loam texture while dystrophic Red Latosols as very clayey (LVd1) and clayey (LVd2 and LVd3) texture. The organic matter content was 2.63, 2.56, 2.67 and $2.45 \mathrm{dag} \mathrm{kg}^{-1}$ for LVd1, LVd2, LVd3, and CXbd, respectively. According to Galindo and Margolis (1989), the permeability was considered slow for the dystrophic Red Latosols and moderate for the Cambisol.

The considerable organic matter and clay content of the dystrophic Red Latosols provide more resistance to the erosive process. Furthermore, these soils have a high effective depth and well-developed structure, which favors the water infiltration and slow-down the runoff. In the case of Cambisol, even with moderate permeability, the elevated content of sand increases soil susceptibility to disintegration, reduce the resistance to water erosion (Bertol; Almeida, 2000).

Table 2: Values adopted for the coefficients of land use and management $\left(X_{a}\right)$ and the coefficient of visible erosion features $(\varphi)$ in the Coroado Stream Hydrographic Sub-basin, Alfenas, southern Minas Gerais, Brazil.

\begin{tabular}{ccccc}
\hline Land use classes & Area (ha) & Area (\%) & $X_{a}$ & $\Phi$ \\
\hline Coffee & 406.89 & 40.05 & 0.6 & 0.5 \\
Forest & 303.50 & 29.87 & 0.1 & 0.1 \\
Corn & 65.51 & 6.45 & 0.7 & 0.7 \\
Sugarcane & 60.11 & 5.92 & 0.7 & 0.6 \\
Eucalyptus & 38.43 & 3.78 & 0.8 & 0.6 \\
Pasture & 13.09 & 1.29 & 0.5 & 0.5 \\
Access roads & 39.90 & 3.93 & 1.0 & 0.8 \\
Deposition area & 42.02 & 4.13 & - & - \\
Facilities & 14.44 & 1.42 & - & - \\
Drainage & 32.11 & 3.16 & - & - \\
\hline
\end{tabular}

Notes: Deposition area (15 m around the entire drainage network), covered with forest. 
The protection coefficient $\left(\mathrm{X}_{\mathrm{a}}\right)$ of the sub-basin area was 0.44 , which indicates good vegetation cover rate. The average coefficient of visible erosion features $(\varphi)$ was 0.39 , indicating a dominance of laminar erosion. The access roads presented the highest indexes values of $\varphi$ factor (0.8). The area presents a mean slope $\left(\mathrm{I}_{\mathrm{sr}}\right)$ of $14.49 \%$, with the predominance of rolling relief, which favors the runoff process and consequently, the sediment removal and transportation.

The coefficient of erosion $(Z)$ ranged from 0.009 to 1.178 , with an average of 0.272 . The sub-basin showed a predominance of low-intensity erosion and among the land uses, coffee cultivation area showed lower erosion intensity, classified as weak to moderate, while the access roads, due to bare soil and the high $\varphi$ factor value, exhibited a higher erosion intensity, classified as strong to severe, according to the Gavrilovic (1988) classification (Figure 3A).

Annual erosion $\left(\mathrm{W}_{\mathrm{yr}}\right)$ of the sub-basin was $12,478.94 \mathrm{Mg}$ year ${ }^{-1}$. The $\mathrm{W}_{\mathrm{yr}}^{\mathrm{yr}}$ value considers both the sediments generated that reach the water bodies or the low sub-basin points and the soil retained in relief depressions (Gavrilovic, 1988). The real soil loss $\left(\mathrm{G}_{\mathrm{yr}}\right)$ is determined based on the retention coefficient $\left(\mathrm{R}_{\mathrm{u}}\right)$, which presented a value of 0.142 , indicating that $14.20 \%\left(1,772.01 \mathrm{Mg}\right.$ year $\left.^{-1}\right)$ of the sediments reach the lower points of the area, while the remainder $\left(85.80 \%\right.$, or $10,706.93 \mathrm{Mg}$ year $\left.^{-1}\right)$ is retained.

The value of $1,772.01 \mathrm{Mg}$ year $^{-1}$ represents the total soil loss, with an estimated average of $1.74 \mathrm{Mg} \mathrm{ha}^{-1}$ year $^{-1}$. The observed mean was close to that found by Mendes Júnior et al. (2018), which evaluated the potential soil losses with the RUSLE method in the same region obtained a value of $1.52 \mathrm{Mg} \mathrm{ha}^{-1}$ year $^{-1}$. The data also agree with the results obtained by Tavares et al. (2019), who observed losses of $1.46 \mathrm{Mg} \mathrm{ha}^{-1}$ year $^{-1}$ using EPM. The proximity of the results with the values of the literature indicates precision and reliability in the estimation performed by the method.

The spatialization of soil losses in the sub-basin presented a maximum value of $9.10 \mathrm{Mg} \mathrm{ha}^{-1}$ year $^{-1}$. About $95.0 \%$ of the area showed soil losses lower than $4 \mathrm{Mg} \mathrm{ha}^{-1}$ year $^{-1}$ and only $2.5 \%$ exceeds $6 \mathrm{Mg} \mathrm{ha}^{-1}$ year $^{-1}$ (Figure $3 \mathrm{~B}$ ).

The average soil losses by use classes ranged from 0.06 to $7.56 \mathrm{Mg} \mathrm{ha}^{-1}$ year $^{-1}$ (Table 3). The forest had the lowest loss rate $\left(0.06 \mathrm{Mg} \mathrm{ha}^{-1}\right.$ year $\left.^{-1}\right)$, corresponding to $1.13 \%$ of the loss rate of the area. According to Anache et al. (2017), the little soil loss in native vegetation is due to dense vegetation cover, which provides slow flow, and lower erosion rates compared to pastures and crops under conventional tillage.

The access roads had the highest average soil loss, with $7.56 \mathrm{Mg} \mathrm{ha}^{-1}$ year $^{-1}$, representing $17.02 \%$ of the subbasin soil loss. The presence of bare soil contributed to the higher magnitude of the erosive process. Furthermore, the intense traffic of the agricultural machinery in the access roads generates soil compaction, which interfere with the infiltration of water and contributes to the production of sediment and losses through the runoff (Mendes Júnior et al., 2018).

Soil losses in the coffee areas range from 0.87 to $3.45 \mathrm{Mg} \mathrm{ha}^{-1}$ year ${ }^{-1}$ with an average of $2.12 \mathrm{Mg} \mathrm{ha}^{-1}$ year $^{-1}$. Regarding the total growing area, the losses estimate were $862.61 \mathrm{Mg}$ year $^{-1}$. The erosion rate in the coffee area was one of the lowest in the land use classes, confirming the efficiency of the conservation management practices adopted.
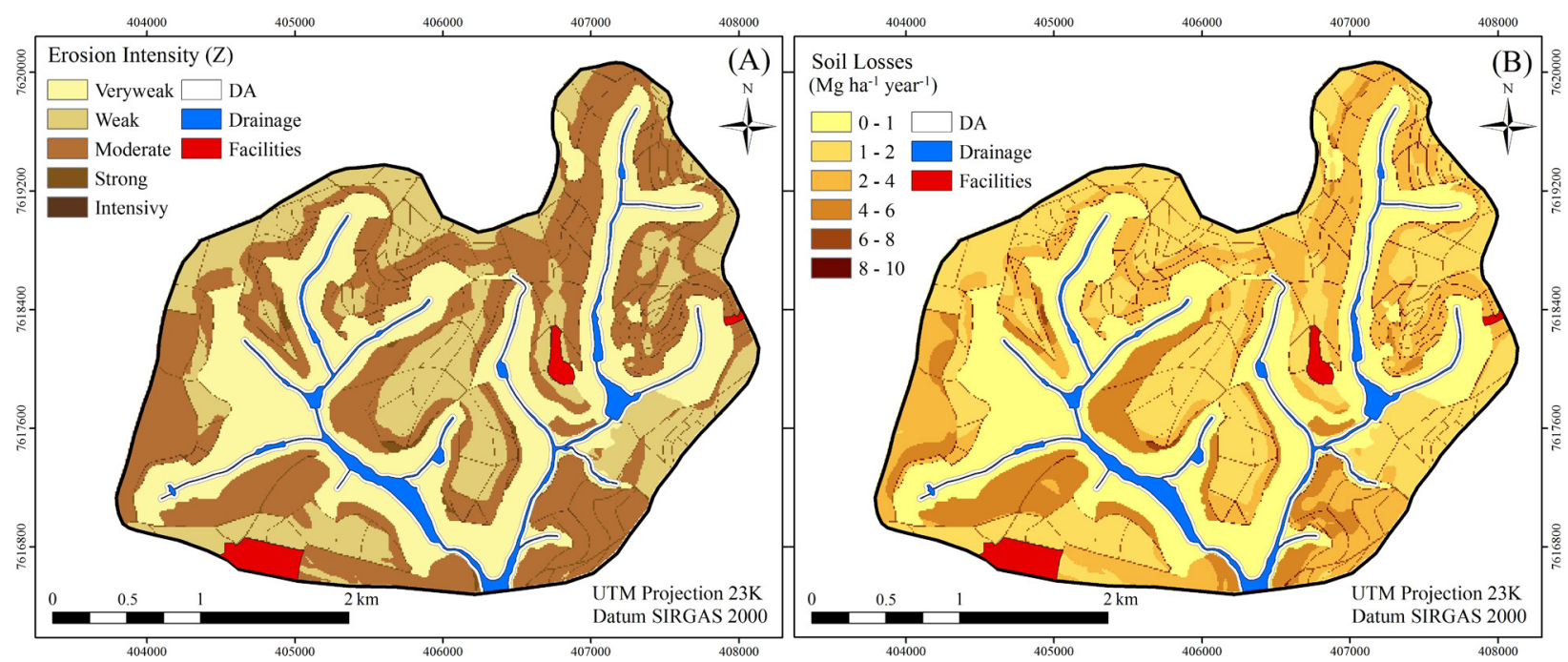

Figure 3: Erosion Intensity Map (Z) (A) and Map of the spatial distribution of soil losses (B) in the Coroado Stream Sub-basin, Alfenas, south of Minas Gerais, Brazil. Notes: Deposition area (DA). 
Table 3: Soil losses estimated by the Erosion Potential Method in each land use classes in the Coroado Stream Sub-basin, Alfenas, south of Minas Gerais, Brazil.

\begin{tabular}{crcccc}
\hline \multirow{2}{*}{ Land use classes } & \multicolumn{2}{c}{ Area } & Mean soil loss & Total soil loss & $\begin{array}{c}\text { Contribution to } \\
\text { total soil loss }\end{array}$ \\
\cline { 2 - 6 } & \multicolumn{1}{c}{ ha } & $\%$ & Mg ha-1 year $^{-1}$ & Mg year & \% \\
\hline Coffee & 406.89 & 40.05 & 2.12 & 862.61 & 48.62 \\
Forest & 303.50 & 29.87 & 0.06 & 18.21 & 1.13 \\
Corn & 65.51 & 6.45 & 3.40 & 222.73 & 12.58 \\
Sugarcane & 60.11 & 5.92 & 3.04 & 182.73 & 10.31 \\
Eucalyptus & 38.43 & 3.78 & 4.15 & 159.48 & 9.00 \\
Pasture & 13.09 & 1.29 & 1.88 & 24.61 & 1.34 \\
Access roads & 39.90 & 3.93 & 7.56 & 301.64 & 17.02 \\
Deposition area* & 42.02 & 4.13 & - & - & - \\
Facilities* & 14.44 & 1.42 & - & - & - \\
Drainage* & 32.11 & 3.16 & - & - & - \\
\hline Total & 1016 & 100 & - & 1772.01 & 100 \\
\hline
\end{tabular}

* Areas not considered in the calculation of soil losses, because they do not participate in sediment generation.

The management of the vegetation between the coffee lines used to quantify the coverage factor $\left(\mathrm{X}_{\mathrm{a}}\right)$ is the main factors that contributed to the low soil loss estimates. Good soil cover between the lines, especially during the rainy season, allows more water infiltration and avoids runoff process and, consequently, soil losses (Sánchez et al., 2015).

The erosion estimate in the coffee area was higher than Sánchez et al. (2015) that evaluated the soil loss in Costa Rica using experimental plots and found an average of $1 \mathrm{Mg} \mathrm{ha}^{-1}$ year ${ }^{-1}$. Scharrón and Sánchez (2017) also obtained lower estimates in a rain simulation experiment in areas with coffee cultivation in Puerto Rico, where the erosion rate for weed-covered surfaces was $1.1 \mathrm{Mg} \mathrm{ha}^{-1}$ year ${ }^{-1}$. In addition, Carvalho et al. (2007) in experimental plots under coffee cultivation in Brazil obtained soil losses range from 0.11 to $0.29 \mathrm{Mg} \mathrm{ha}^{-1}$ year $^{-1}$ in different conservation management conditions. The highest value observed in the study area can be explained by the fact that EPM presented an overestimate of soil losses compared to field experiments (Noori; Siadatmousavi; Mojaradi, 2016; Stefanidis; Stathis, 2018).

Corn crop showed an average soil loss of 3.40 $\mathrm{Mg} \mathrm{ha}^{-1}$ year $^{-1}$ contributing with $12.58 \%$ of the subbasin losses $\left(222.73 \mathrm{Mg} \mathrm{ha}^{-1}\right)$. The conventional tillage with mechanized planting adopted in this use enhances the erosion process due to the aggregate disintegration and leaves the soil provisionally discovered. However, because these areas are located mainly in smooth reliefs, with lower flow velocity, the erosive process tends to be minimized.

Sugarcane contributes with $10.31 \%$ of soil losses, with an average loss of $3.04 \mathrm{Mg} \mathrm{ha}^{-1} \mathrm{year}^{-1}$. In this case, Couto Júnior et al. (2019) using Universal Soil Loss Equation (USLE) to estimate soil losses in the State of São Paulo obtained values higher than $5 \mathrm{Mg} \mathrm{ha}^{-1}$ year ${ }^{-1}$. The estimates of Martins Filho et al. (2009) reported losses of $5.81 \mathrm{Mg} \mathrm{ha}^{-1}$ year $^{-1}$ when using simulated rain in plots with sugarcane without straw cover. Therefore, the lowest soil loss estimation for sugarcane in the Coroado sub-basin may be due to the presence of straw from the previous crop.

The good state of the forage and the uniform canopy provide to the pasture the lowest erosion rate among the agricultural use classes, estimate in $1.88 \mathrm{Mg}$ ha $^{-1}$ year ${ }^{-1}$, evidencing the potential of pastures, especially when well-managed, on soil protection process. Pasture contributed with $1.34 \%$ to the sub-basin loss, corresponding to $24.61 \mathrm{Mg}$ year $^{-1}$. Eucalyptus showed the highest soil loss average among the crops, estimate in $4.15 \mathrm{Mg} \mathrm{ha}^{-1}$ year $^{-1}$. This result is due to the plants cultivated down the hill and in the steep reliefs (Pruski, 2009). Nevertheless, the high rate of vegetal residues on the soil surface from the eucalyptus and the already established canopy of the plants contribute to decreasing the erosive intensity. 
Soil loss tolerance $(\mathrm{T})$ values ranged from 4.75 to 7.26 $\mathrm{Mg} \mathrm{ha}^{-1}$ year $^{-1}$. The parameters used in the T calculations are present in table 4 . The $\mathrm{T}$ values corroborate with the results found by Tavares et al. (2019) for a dystrophic Red Latosol in the south of Minas Gerais. However, Cândido et al. (2014) studying a dystrophic Red Latosol in the Mato Grosso do Sul State found values of 9 to $10 \mathrm{Mg} \mathrm{ha}^{-1}$ year $^{-1}$. The Cambisol present a low $\mathrm{T}$ limit compared to the dystrophic Red Latosols manly due to the small effective depth.

The EPM pointed out that $1.0 \%$ of the subbasin presented soil losses above the $\mathrm{T}$. The losses were concentrated in places with higher slope and access roads due to the presence of bare soil. Thus, these areas should be prioritized in the adoption of mitigating measures. As alternatives, the use of gravel and containment basins drastically reduce erosion rates compared to untreated conditions (Scharrón; Sánchez, 2017).

Agricultural crops showed soil losses below the $\mathrm{T}$, even with the adoption of poor management practices, such as conventional tillage and unlevel planting. The low soil erosion rates occurred due to factors that contribute to mitigating the erosive process such as smooth slopes, soil cover, and spontaneous vegetation management. Nevertheless to the fact that sediment production is below to the $\mathrm{T}$, soil conservation practices should be expanded mainly in areas with higher slope, seeking to minimize erosion to levels close to natural vegetation conditions (Anache et al., 2017), because, in long-term, even small losses are harmful.

Maintenance of soil cover by spontaneous vegetation management or by crop residue input increases water infiltration and thus decreases runoff and sediment production (Sánchez et al., 2015). In the case of eucalyptus, it is necessary to carry out the terracing and after the end of the crop cycle, to introduce crop cultivated in level in the succeeding planting.
The area cultivated with corn was previously occupied with coffee, which was eradicated as a nematodes control method. Therefore, the erosion process could transport the sediments contaminated with the pathogen to other areas, resulting in the spread of the parasite (Godoy; Bergamim Filho; Salgado, 1997). No-till implementation could reduce soil erosion due to remaining straw from the earlier crop, providing higher soil protection, and increasing the amounts of organic matter, which improves soil aggregation and infiltration (Bertoni; Lombardi Neto, 2012). In this case, erosion control will still perform as an agronomic practice integrated with nematode control.

The EPM showed that the erosion severity occurs mainly in areas with bare soil, with higher slope and in crops with no conservationist agronomic practices. The results allowed identifying areas with soil loss above the $\mathrm{T}$, providing valuable information for the reduction of soil degradation. According to Amorim et al. (2010), erosion prediction models present greater errors in the lowest soil loss rates, while areas with higher losses present smaller errors, and these are precisely those areas that should be identified as a priority for adoption of mitigation measures.

It is important to emphasize that despite the facility of EPM application, the accuracy of the data analyzed depends mainly on the experience and knowledge of the specialists who, based on field observations and sample data, determine the values of erosion coefficients, since the factors $\mathrm{X}_{\mathrm{a}}$ and $\mathrm{Y}$ present high sensitivity of variation, interfering decisively in the results provided by EPM (Shahabi et al., 2016; Dragičević; Karleuša; Ožanić, 2017).

The data validation was not performed in the field with experimental plots, which is a relevant for future research. However, the results found are similar to the literature data for soil losses in the same region and consistent with the Revised Universal Soil Loss Equation (RUSLE) (Renard et al., 1997), the method most used and adapted to

Table 4: Variables used in the calculation of the Soil Loss Tolerance $(T)$ limit in the Coroado Stream Hydrographic Sub-basin, Alfenas, south of Minas Gerais, Brazil.

\begin{tabular}{ccccccc}
\hline \multirow{2}{*}{ Soil types } & $\mathrm{h}$ & $\mathrm{r}_{\mathrm{a}}$ & $\mathrm{M}$ & $\mathrm{p}$ & $\mathrm{Ds}$ & $\mathrm{T}$ \\
\cline { 2 - 7 } & $\mathrm{cm}$ & $\mathrm{adm}$ & Dimen. & Dimen. & $\mathrm{kg} \mathrm{dm}^{-3}$ & $\mathrm{Mg} \mathrm{ha}^{-1}$ year $^{-1}$ \\
\hline LVd1 & 100 & 1.0 & 0.85 & 0.7 & 1.22 & 7.26 \\
LVd2 & 100 & 1.0 & 0.85 & 0.7 & 1.21 & 7.20 \\
LVd3 & 100 & 1.0 & 0.85 & 0.7 & 1.15 & 6.84 \\
CXbd & 71 & 0.9 & 0.7 & 0.85 & 1.25 & 4.75 \\
\hline
\end{tabular}

Notas: $\mathrm{h}=$ effective soil depth; $r_{a}=$ relationship that expresses, together, the effect of the textural relation between the horizons $\mathrm{B}$ and $\mathrm{A}$ and the clay content of the A horizon; $\mathrm{m}=$ factor that expresses the organic matter content in the $0-20 \mathrm{~cm}$ soil depth; $\mathrm{p}=$ soil permeability factor; Ds = soil density; $\mathrm{T}$ = Soil loss tolerance; Dimen. = dimensionless; LVd1 = dystrophic Red Latosol in flat to slightly rolling relief; LVd2 = in rolling relief; LVd3 = in strongly rolling relief; CXbd = dystrophic Tb Haplic Cambisol. 
tropical geographic and climatic conditions (Mendes et al., 2018; Tavares et al., 2019). Furthermore, the EPM application already fulfilled the purpose of being an accessible predictive tool to estimate soil losses by water erosion with low cost and less complex than field experiments.

\section{CONCLUSIONS}

The Erosion Potential Method was used to estimate the soil losses in a sub-basin under tropical edaphoclimatic conditions, with predominant coffee cultivation, besides areas occupied with forest, corn, sugarcane, eucalyptus, pasture and access roads. The sub-basin presented an average soil loss estimated at $1.74 \mathrm{Mg} \mathrm{ha}^{-1}$ yearr $^{-1}$, which was positively influenced by conservationist management adopted in the coffee cultivation that range from 0.87 $\mathrm{Mg} \mathrm{ha}^{-1}$ year $^{-1}$ to $3.45 \mathrm{Mg} \mathrm{ha}^{-1}$ year $^{-1}$ with a mean of 2.12 $\mathrm{Mg} \mathrm{ha}^{-1}$ year $^{-1}$. The highest losses were concentrated in access roads with bare soil and eucalyptus areas. Only $1.0 \%$ of the sub-basin presented losses above the soil loss tolerance limit, which ranged from 4.75 to $7.26 \mathrm{Mg}$ ha $^{-1}$ year $^{-1}$. The Erosion Potential Method was shown to be an efficient and low-cost tool to estimate soil losses in tropical edaphoclimatic conditions and to identify areas more susceptible to the erosive process, and demand mitigation measures to avoid environmental degradation.

\section{ACKNOWLEDGEMENTS}

The authors thank the Fundação de Amparo à Pesquisa do Estado de Minas Gerais (FAPEMIG) for the scholarship offered to the first author. The Departamento de Ciência do Solo da Universidade Federal de Lavras - UFLA, for conducting the soil analyzes. To Ipanema Agrícola S. A. for funding the research and conceding the study area.

This study was financed in part by the Coordenação de Aperfeiçoamento de Pessoal de Nível Superior - Brasil (CAPES) - Finance Code 001.

\section{REFERENCES}

AMORIM, R. S. S. et al. Avaliação do desempenho dos modelos de predição da erosão hídrica USLE, RUSLE e WEPP para diferentes condições edafoclimáticas do Brasil. Engenharia Agrícola, 30(6):1046-1049, 2010.

ANACHE, J. A. A. et al. Runoff and soil erosion plot-scale studies under natural rainfall: A meta-analysis of the Brazilian experience. Catena, 152(1):29-39, 2017.

AVANZI, J. C. et al. Spatial distribution of water erosion risk in a watershed with eucalyptus and Atlantic Forest. Ciência e Agrotecnologia, 37(5):427-434, 2013.
BERTOL, I.; ALMEIDA, J. A. Tolerância de perda de solo por erosão para os principais solos do estado de Santa Catarina. Revista Brasileira de Ciência Solo, 24(3):657-668, 2000.

BERTONI, J.; LOMBARDI NETO, F. Conservação do solo. $3^{a}$ edição, São Paulo: Ícone, 2012. 360p.

BLAKE, G. R.; HARTGE, K. H. Bulk density. In: KLUTE, A. Methods of soil analysis. 2. ed. Madison: American Society of Agronomy, 1986. v.1, p.363-375.

BRASIL. Ministério da Agricultura, Pecuária e Abastecimento. Café no Brasil 2018. Available in: <http://www.agricultura. gov.br/assuntos/politica-agricola/cafe/cafeicultura brasileira>. Access in: February, 18, 2019.

CÂNDIDO, B. M. et al. Erosão hídrica pós-plantio em florestas de eucalipto na bacia do rio Paraná, no leste do Mato Grosso do Sul. Revista Brasileira de Ciência do Solo, 38(5):1565-1575, 2014.

CARVALHO, R. et al. Erosão hídrica em Latossolo Vermelho sob diversos sistemas de manejo do cafeeiro no Sul de Minas Gerais. Ciência e Agrotecnologia, 31(6):1679-1687, 2007.

COUTO JÚNIOR, A. A. et al. Land use changes associated with the expansion of sugar cane crops and their influences on soil removal in a tropical watershed in São Paulo State (Brazil). Catena, 172(1):313-323, 2019.

DRAGIČEVIĆ, N.; KARLEUŠA, B.; OŽANIĆ, N. Erosion potential method (Gavrilović Method) sensitivity analysis. Soil \& Water Research, 12(1):51-59, 2017.

EFTHIMIOU N. et al. Assessment of soil susceptibility to erosion using the EPM and RUSLE Models: The case of Venetikos river catchment. Global NEST Journal, 18(1):164-179, 2016.

EMBRAPA, Empresa Brasileira de Pesquisa Agropecuária. Manual de métodos de análise do solo. 2. ed. rev. Rio de Janeiro: Embrapa Solos, 2011. 225p.

EMBRAPA, Empresa Brasileira de Pesquisa Agropecuária. Sistema brasileiro de classificação de solos. $3^{a}$ edição. Brasília, DF: Embrapa Solos, 2013. 353p.

ESRI, Environmental Systems Research Institute - Inc. ARCGIS Professional GIS for the desktop version 10.3. Redlands, Califórnia, EUA, Software, 2015. Available in: <http:// desktop.arcgis.com/en/arcmap/10.3/get-started/quickstart-guides/arcgis-desktop-quick-start-guide.htm>. Access in: January, 10, 2019.

GALINDO, I. C. L.; MARGOLIS, E. Tolerância de perdas por erosão para solos do estado de Pernambuco. Revista Brasileira de Ciência do Solo, 13(1):95-100, 1989. 
GAVRILOVIC, S. The use of empirical method (erosion potential method) for calculating sediment production and transportation in unstudied or torrential streams. In: WHITE, W. R. et al. International Conference on River Regime, Chichester, 1988. p. 411-422.

GEE, G. W.; BAUDER, J. W. Particle-size analysis. In: KLUTE, A. Methods of soil analysis: physical and mineralogical methods. 2. ed. Madison: American Society of Agronomy, 1986. v.1, p.383-411.

GODOY, C. V.; BERGAMIM FILHO, A.; SALGADO, C. L. Doenças do cafeeiro (Coffea arabica L.). In: KIMATI, H. et al. Manual de fitopatologia, Volume 2: Doenças das Plantas Cultivadas. São Paulo: Editora Agronômica Ceres, 1997. v.7, p.178-193.

HERNANI, L. C. et al. A erosão e seu impacto. In: MANZATTO, C. V.; FREITAS JÚNIOR, E.; PERES, J. R. R. Uso agrícola dos solos brasileiros. Rio de Janeiro: Embrapa Solos, 2002. v.5, p.47-60.

IBGE, Instituto Brasileiro de Geografia e Estatística. Carta Topográfica do município de Alfenas (FOLHA SF 23-11-3), 1970. Available in: <https://mapas.ibge.gov.br/basese-referenciais/bases-cartograficas/cartas.html>. Access in: February, 18, 2019.

INMET, Instituto Nacional de Meteorologia. Estações pluviométricas convencionais. 2019. Ministério da Agricultura, Pecuária e Abastecimento (MAPA). Available in: <http://www.inmet.gov.br/portal/index.php?r=bdmep/ bdmep>. Access in: February, 18, 2019.

INPE, Instituto Nacional de Pesquisas Espaciais. Divisão de Geração de Imagens (DIDGI). Ministério da Ciência, Tecnologia, Inovações e Comunicações. Available in: <http:// www.dgi.inpe.br/catalogo/>. Access in: February, 10, 2019.

LI, L. et al. An overview of soil loss tolerance. Catena, 78(2):9399, 2009.

MARTINS FILHO, M. V. et al. Perdas de solo e nutrientes por erosão num Argissolo com resíduos vegetais de cana-deaçúcar. Engenharia Agrícola, 29(1):8-18, 2009.

MCBRATNEY, A. B.; SANTOS, M. L. M.; MINASNY, B. On digital soil mapping. Geoderma, 117(2):3-52, 2003.

MENDES JÚNIOR, $\mathrm{H}$. et al. Water erosion in Oxisols under coffee cultivation. Revista Brasileira de Ciência do Solo, 42(1):1-14, 2018.

NOORI, H.; SIADATMOUSAVI, M. S.; MOJARADI, B. Assessment of sediment yield using RS and GIS at two sub-basins of Dez Watershed, Iran. International Soil and Water Conservation Research, 4(3):199-206, 2016.
PROCHNOW, D. et al. Razão de perdas de terra e fator C da cultura do cafeeiro em cinco espaçamentos, em Pindorama (SP). Revista Brasileira de Ciência do Solo, 29(1):91-98, 2005.

PRUSKI, F. F. Conservação de solo e água: práticas mecânicas para o controle da erosão hídrica. 2. ed. Viçosa, MG: Universidade Federal de Viçosa; 2009. 279p.

RENARD, K. G. et al. Predicting soil erosion by water: A guide to conservation planning with the Revised Universal Soil Loss Equation (RUSLE). Washington: United States Department of Agriculture, 1997. 384p.

SÁNCHEZ, M. V. et al. Temporal dynamics of runoff and soil loss on a plot scale under a coffee plantation on steep soil (Ultisol), Costa Rica. Journal of Hydrology, 523(1):409-426, 2015.

SANTOS, R. D. et al. Manual de descrição e coleta de solos no campo. 5. ed. Viçosa: Sociedade Brasileira de Ciência do Solo SBCS, Empresa Brasileira de Pesquisa Agropecuária - Embrapa, Centro Nacional de Pesquisa de Solos - Cnps, 2005. 100p.

SCHARRÓN, C. E. R.; SÁNCHEZ, Y. F. Plot, farm, and watershedscale effects of coffee cultivation in runoff and sediment production in western Puerto Rico.Journal of Environmental Management, 202(1):126-136, 2017.

SHAHABI, H. et al. Soil erosion hazard mapping in central Zab Basin using EPM model in gis environment. International Journal of Geography and Geology, 5(11):224-235, 2016.

SPALEVIC, V. IntErO, Intensity of Erosion and Outflow. Version 1.0. Podgorica: UniverzitetCrne Gore, 2011. Available in: $<$ www.agricultforest.ac.me/Spalevic/IntErO>. Access in: January, 10, 2019.

SPAROVEK, G.; VAN LIER, Q. J.; DOURADO NETO, D. D. Computer assited Köeppen climate classification: Case study for Brasil. International Journal of Climatology, 27(2):257-266, 2007.

STEFANIDIS, S.; STATHIS, D. Effect of climate change on soil erosion in a mountainous mediterranean catchment (Central Pindus, Greece). Water, 10(1469):1-12, 2018.

TAVARES, A. S. et al. Modeling of water erosion by the erosion potential method in a pilot subbasin in southern Minas Gerais. Semina: Ciências Agrárias, 40(2):555-572, 2019.

USDA, United States Department of Agriculture. Soil taxonomy: A basic system of soil classification for making and interpreting soil surveys. 2 . ed. Washington: USDA, 1999. $871 \mathrm{p}$.

WISCHMEIER, W. H; SMITH, D. D. Predicting rainfall erosion losses. A guide to conservation planning. 1th. Washington: United States Department of Agriculture. Supersedes Agriculture Handbook. 1978. 58p. 